Artigos 



\title{
Una estela sarmientina: gauchos y soldados A track sarmientina: gauchos and soldiers
}

\author{
Pablo Rocca \\ Universidad de la República (Montevideo, Uruguay)
}

Resumen: Este artículo tratará, en el tiempo que la historiografía uruguaya llama la Guerra Grande, es decir entre 1840 y tantos y 1851, en el apogeo del rosismo, de dos casos de oralidad en situaciones culturales en que las ideas de Sarmiento inciden, directa o indirectamente, en el quehacer poético de la nueva forma que crece como una marea incontenible por hojas, gacetas y periódicos de las dos orillas del Plata. Un caso, pertenece al bando unitario-colorado y otro al rosistaoribista. En los dos se traman el sujeto popular, las representaciones de su voz con las hipotéticas fuentes orales y otros discursos que tratan de capturar su atención, su voluntad y, sobre todo, su lealtad a una fuerza enemiga mortal de la otra.

Palavras-chave: Género gauchesco. Imágenes caricaturales. Representación.

Guerra Grande

\begin{abstract}
This article will address, at the time that uruguayan historiography calls the Great War, namely between 1840 and 1851, at the height of rosismo, two cases of oral cultural situations in which the ideas of Sarmiento reflect, directly or indirectly, the poetic task which grows as a wild wave of sheets, magazines and newspapers on both sides of Prata. A case belongs to the unit side of colorado and the other to orbista. The two cases deal about the popular subject, the representations of her voice with the hypothetical oral sources and other discourses that attempt to capture your attention, your wish and, above all, his loyalty as a mortal enemy of the other.
\end{abstract}

Keywords: Gaucho genre. Caricatured images. Representation. Great War.

Al tiempo que denostaba la barbarie rural, Sarmiento fue el primero en elogiar la capacidad de los trovadores camperos en las primeras páginas del Facundo (1845). Poco después también fue de los primeros en reflexionar sobre la fortuna retórica e ideológica de esta literatura. Cuando apenas pisó Montevideo, rumbo a la ansiada Europa, Sarmiento anotó en su diario que los versos de Hilario Ascasubi y los de Hidalgo estaban "en boca de todos". Con su frecuente pasión se exaltó con el pasaje del primer "Diálogo patriótico interesante entre Jacinto Chano y Ramón Contreras" (1821), en el que se llama a la unión, la paz y el respeto al trabajo. Sarmiento dijo en esos apuntes que Ascasubi era "el primer bardo pleveyo (sic)” (Sarmiento, 1993: 50-51). Pero, ¿quiénes eran esos todos? ¿Los plebeyos o los que los que se apropian de su voz? Estamos, es claro, ante el caso de una lúcida construcción ideológica que ve las posibilidades de un 
discurso sin ver el día a día de esos a los que busca educar, a esos que en 1845 -según el testimonio del ilustrado oribista Francisco Solano Antuña-, atenacea "la miseria publica [que] és muy grande: incesantemente se acercan los pobres de ambos sexos pidiendo limosna, ó proponiendo en venta sus ropas, é insignificantes adornos" (Antuña, 1974: 481). Difícil que estos hambrientos celebraran el discurso poético de la conciliación. Aun más: difícil que supieran siquiera leer.

Pero a pesarde su errática definición, Sarmiento tocóun nervio sensible sobre el que siguió debatiéndose durante más de un siglo. ¿La gauchesca es un género popular en tanto se arrima a las "clases subalternas" -para decirlo con el paradigma de Gramsci- o porque estos sectores populares adoptan su discurso? ¿El poeta popular es un sujeto que pertenece a ese conjunto social o lo interpreta? De nuevo, estas preguntas involucran una noción de lo popular que, en consecuencia, no puede eludirse si se quiere enfocar el problema con seriedad y que envuelve tres grandes planos: cuestiones estéticas; asuntos materiales, que en determinados objetos son difícilmente discernibles y que incluyen a los siempre escurridizos destinatarios. Como se verá, se ponen en juego diferentes niveles de la poesía (se diría, incluso, de la cultura) que llamamos "alta" en contacto o en conflicto -depende cómo se lo aprecie- con lo folklórico y sus figuras intermedias.

Estudiando las marcas de oralidad de la ficción medieval europea, Paul Zumthor distinguió entre tradición oral y transmisión oral: "la primera se sitúa en el tiempo; la segunda, en el presente de la realización”. Entre los tres tipos básicos de oralidad en situaciones culturales que identifica Zumthor, hay dos que podemos aprovechar para el Río de la Plata: una "oralidad mixta", que procede, porque la retoma, de la cultura escrita, y una "oralidad segunda", que viene de la cultura erudita, empeñada en reconstruir ese pasado ágrafo (Zumthor, 1989: 19). Los senderos se abren más que lo que uno sospecha a primera vista, y en el caso latinoamericano, se extiende mucho después de lo que para Europa habría quedado fijado en un tiempo lejano y perdido.

Sobre dos casos cercanos tratará este artículo en el tiempo que la historiografía uruguaya llama la Guerra Grande, es decir entre 1840 y tantos y 1851, en el apogeo del rosismo. Dos casos en que las ideas de Sarmiento inciden, directa o indirectamente, en el quehacer poético de la nueva forma que crece como una marea incontenible por hojas, gacetas y periódicos de las dos orillas del Plata. Un caso, pertenece al bando unitariocolorado y otro al rosista-oribista. En los dos se traman el sujeto popular, las representaciones de su voz con las hipotéticas fuentes orales y otros discursos que tratan de capturar su atención, su voluntad y, sobre todo, su lealtad a una fuerza enemiga mortal de la otra. 
El 23 de marzo de 1843 se publica en El Nacional de Montevideo este aviso sin firma:

Generalmente los soldados de Oribe degüellan las víctimas apuñaleándoles al compás de una canción popular que han parodiado del modo siguiente:

\author{
Tintín de la Aguada \\ tintin del Cordon, \\ gallina guisada, \\ Pato con arroz:- \\ violín, violon! etc.
}

El aviso hace gala de exacto lenguaje técnico, ya que el presunto texto entonado en tan macabro ritual es "popular", y "parodia" una suerte de ronda infantil que, por las referencias a los barrios montevideanos de la Aguada y el Cordón, habría sido inventada en esta pequeña y sitiada ciudad. O, vaya uno a saber, quizá sea la acomodación de una anterior y remota.

Me permito poner en duda la existencia misma de esa versión del canto ingenuo en boca de los soldados de Oribe. En virtud del fenómeno que desata, más apropiado sería entender ese texto como un mecanismo interno del que necesita el género gauchesco para producir un feedback con el lenguaje de la tribu, a partir del cual generar hechos poéticos ligados a las emergencias políticas. Si se defendiera la hipótesis contraria -de todos modos inverificable, ya que el único testimonio de la copla brutal está en el periódico- estaríamos ante un típico fenómeno folklórico, puesto que, como postula Lauro Ayestarán, siempre el "folklore es supervivencia de algo anterior" (Ayestarán, 1968: 78).

Sea como sea, desde la publicación de esos versos crueles y del comentario anejo del redactor anónimo de El Nacional, las páginas de este órgano antioribista empiezan a tapizarse de poemas en que se retoman las líneas iniciales -sólo a veces modificadas-con la finalidad de parodiar el modelo, en el sentido de inversión semántica fuerte que supone toda parodia. Por su lado, la presunta canción de los oribistas reelabora la ronda infantil, con lo que se duplica esa repetición que pauta una diferencia (Hutcheon, 1991: 36). Esto porque si, como propone Linda Hutcheon, el acto paródico presente es capaz de reorganizar estéticamente un material anterior, en el caso lo hace en dos niveles contradictorios. Como si el motivo fuera una metonimia del expediente estructural de la primera gauchesca: la lógica de la guerra injertada en el discurso poético que pretende insertar la dinámica de la oralidad en su cuerpo escrito. Desde esta óptica, el aviso y los versos que lo ilustran funcionan como un disparador intencionado de una serie poético-política que, además, se interroga sobre su propio mecanismo.

Es claro que hay un plan de acción literaria, porque sólo seis días después, el 29 de marzo de 1843, alguien que pudo haber sido Ascasubi, 
publica en El Nacional la "Canción de extramuros". Este nuevo acto de discurso articula la ironía contra la fuerza rosista-oribista con el empleo del código propio de la escritura panfletaria, que se anexa el ritornelo de una onomatopeya infantil expandida desde la primera a la segunda estrofas:

\author{
Tin tin de la Aguada \\ Tin tin del Cordon \\ Ya está agonizando la federacion; \\ Y mientras le cantan \\ El kirieleyson \\ Tengamos la mecha \\ cerca del cañon. \\ Rin rin para Oribe, \\ A Maza rin, ron, \\ Con cuatro bemoles \\ Será el rigodon.
}

La onomatopeza tin tin se remata con otras dos (rin rin y rin ron), simulando el pasaje del inocente timbre al rugido del cañón, que rebaja al enemigo y lo destruye. La potente arma de fuego empleada en legítima defensa pulveriza al solitario y cobarde puñal y, para eso, el poeta acude a la acentuación consonántica y a la figura de la contradanza a fin de armonizar los planos sintáctico, sonoro y semántico. Pero la cosa no queda ahí.

El 13 de abril sale en el mismo periódico "Al cortacabezas Manuel Oribe y comparsa”, firmado por "Dos Urbanos":

Tin tin, á las damas,

Calle del Porton,

¿Tenéis muchas ganas?

¡A fuera simplon!

Os doy un consejo

Amigo Manuel:

Que vuestro esqueleto

No al muro arrimeis. [...]

El poema procura incorporar una variante al sistema de escritura gauchesca: la onomatopeya “tin tin", como otro de sus recursos formularios. Simultáneamente, se entrelaza en una discusión retórica harto relevante para el género. Porque hay que resaltar que, como lo demostró María Fontanella de Weinberg, si bien las formas tuteantes y voseantes siguieron alternándose en la gauchesca, el voseo tendió a imponerse justamente desde la batería de composiciones que Ascasubi dio a conocer en estos mismo años febriles en los que alcanzó la primacía como gauchesco (Fontanella de Weinberg, 
1986: 20). Esta composición muestra que el ataque al enemigo empuja el proceso paródico fundiendo dos vertientes: el abierto rechazo a Manuel Oribe ( A fuera simplon!”) y la manera falsamente cordial de tratamiento (“Amigo Manuel"), todo lo cual se sostiene en un discurso extemporáneo para el lenguaje rioplatense, de suyo ridículo, por la manera castiza en la conjugación de los verbos y pronombres concordantes, proceso que ya había anquilosado el último Hidalgo. Por lo demás, el epíteto "Corta cabezas" añadido a Oribe formaba parte del lenguaje o cuanto menos de las arengas oficiales por esa fecha, como desde el bando blanco-federal lo anota indignado en su diario Francisco Solano Antuña, el 24 de mayo de ese año: "Los italianos dieron musica esta noche al Min ${ }^{\circ}$ Vasquez q.e salió al balcon y grito á toda voz- Muera el Corta cabezas Oribe- muera el tirano Rosas...” (Antuña, 1974: 472-473).

Once días más tarde de publicado el texto antes comentado, el 24 de abril de 1843, la receta se torna subgénero fugaz en "Tin tin dedicado á la Guarnición de la Plaza por el Tambor de la Línea”, larga tirada de versos que Ayestarán -en una investigación aún inédita y en vías de publicaciónatribuye a Fernando Quijano:

Dijo el flaco Oribe Cuando aqui llegó, Dentro de seis días Sin falta entro yó, $[\ldots]$

Tin tin del Cerrito Tin tin del Canelon Tin tin de la parte Que toma un pichón Porque al gaucho Rosas, Mande á esta Nación Que a Montevideo No puedes tomar Con esa gentuza De raza infernal Que pelear no sabe, Y si degollar.

Tin tin del Cerrito Tin de la Ciudad Mucho miedo tienes Acércate mas. [...]

Tin tin del Cerrito Tin del Canelon: Suene la campana, 


\author{
Suene el esquilón \\ Que anuncia la muerte \\ Del degollador $[\ldots]$
}

En este poema aparecen tres novedades y otra posible novación se cimenta en el registro lírico popular rioplatense. Primero, el flamante recurso onomatopéyico deja de presidir la composición para intercalarse en su cuerpo (“Tin tin del Cerrito,/ Tin tin del Canelón” y otras permutaciones del mismo); segundo, se introduce una nota extraña al género gauchesco: la recitación femenina del texto (“Cuando canten las Señoras este Tin, tin pueden cambiar el verso siguiente -en la $6^{a}$ estrofa- que dice: «ni las lavativas». Dígase «ni toda la astucia»"); tercero, en anotación contigua se ofrece una definición del mismo en clave lírico-musical que, además, agrega un dato sobre su circulación comercial:

Este Tin, Tin tiene una música exclusiva compuesta por el TAMBOR, para que la canten las DAMAS COLORADAs, y la que estara de Manifiesto dentro de cuatro dias en la Librería de Hernandez para los que gusten sacar copia, ya que la litografia está parada Merced á un gastador.

En casos como este y algunos otros de la misma época -como el que cité antes-, la voz que habla en el poema no se ajusta estrictamente a las convenciones del género gauchesco. No hay casi locuciones orales (sólo, tal vez, “rempujón” y su consonante "mancarrón”), nada remite a la parafernalia criolla (la preparación del mate, las prendas del apero, etc.) y -lo más importante- se acentúa la condición de soldado en el hablante poético y no de gaucho-soldado. Quien emite su voz integra como Tambor de línea las fuerzas que repelen el asedio del "gaucho Rosas" y el patricio Oribe, al últimos de los cuales se ve como un ridículo títere y por eso mismo se lo caricaturiza. Los dos, bárbaro y falso civilizado, son los jefes supremos de otros soldados, los asesinos, las contrafiguras de quienes desde estos poemas escritos en Montevideo.

El Tambor de línea trata de cumplir el ideal sarmientino del sujeto popular que usa las palabras como armas para defender los altos ideales de la civilización. Como en el programa del autor del Facundo, el ejército sería el primer paso para la transformación del gaucho en ciudadano, por eso la voz del casi desgauchizado hablante-soldado atenúa ciertos recursos del género, mientras le toma en préstamo otros elementos que esta poesía había naturalizado en la comarca: la polémica, el panfleto, la invectiva y la sátira, aquellos que según Marc Angenot pertenecen a los "discursos agónicos” (Angenot, 1982).

En cualquier caso, los dos (gaucho-bárbaro y soldado-civilizado) pertenecen a los sectores populares, y quien los hace hablar es el mismo hombre de la ciudad, el de siempre. A veces, si defiende la causa que este 
reputa justa, el sujeto rural será el aliado de los ideales de la civilización y su arquetipo, el caudillo, será tal no sólo porque compendia las virtudes criollas sino porque sabe leer y escribir. Hasta Luis Pérez en 1830 había pintado de ese modo a su admirado Rubio Rosas, el que desconfiaba de "los sabios de la Tierra" que "nos han de enredar/ con sus malditas teorías", pero no lo hacía por ignorante sino con conocimiento de causa: "Porque era el ilustrao del pago,/ Y ansí todos a el no más/ Venían a consultarlo" (En Rodríguez Molas, 1957: 23).

En el poema en que habla el Tambor de línea se inventa una categoría abstracta de soldado que abandona las características coloridas del tipo del país, y así se borra el rastro de civilización posible en el gaucho y su conductor. Por último, el señalamiento de una lectora-intérprete del “Tin tin dedicado á la Guarnición de la Plaza [...]”, reforzado por la nota final, indica la variante de una poesía que no deja de ser de guerra ni de asuntos de la polis (cosas de hombres), pero que pretende incorporar un coro de mujeres como base de apoyo para la empresa unitaria de salvarse de la barbarie. Y para darle lugar a la mujer debe limar la aspereza de un vocablo algo subido de tono, sustituyendo "lavativas" por "toda la astucia". Los redactores de El Nacional quieren imponer el género entre los montevideanos a través de la fórmula nueva, ofreciendo a la venta una composición que busca colocarla en hoja suelta, doble perpetuación del objeto y el mensaje. Quien aparece como mediador privilegiado de esta tarea es el librero Jaime Hernández, depositario de las mediación para el ensanche del universo letrado, cuya trayectoria viene a sintetizar las expectativas y los límites de este proyecto.

Las composiciones que apelan al procedimiento onomatopéyico no cesan de inmediato, y aun continúan desafiando a la gauchesca apostando más alto por la variante del soldado-civilizado en un texto que llega a identificarse con la voz colectiva de la sociedad urbana, como la extensa y anónima "Cancion de la sociedad popular de Buenos-Ayres alusiva á su moral, á su política y á sus gloriosos trofeos”. Publicada el 23 de mayo, comienza con una estrofa que al cabo de las siguientes, se sugiere que debe ser entonada como estribillo:
Al tin tin del tigre
Al tin tin de Rosas
Todo el mundo gime,
Todo el mundo llora
Menos la mas-horca.
De misericordia
Catorce preceptos
Tiene la mas-horca
Que son el consuelo 
De un federal neto.

Al tintin, etc.

Siete corporales

Deben ser y son

Que han de completarse

Con esta canción

Violín y violón.

Al tintin, etc.

El 5 de junio, por fin, el mayor orfebre del género, Ascasubi, firma en El Nacional la hoy bien conocida "Media caña salvaje del Rio Negro". Dentro de esta denominación musical a la que pretende dar vida con sus versos, Ascasubi recupera la fórmula original en cuanto estribillo alternado, y cruza en todas sus posibilidades tres espacios físicos montevideanos logrando un vaivén fónico y semántico con alcances lúdicos: “Tin tin por la Aguada/ Tin tin á el Cordon" (estr. 1); "Tin tin de la Aguada/ Tin tin del Cordon" (estrs. 2, 4, 7, 8 y 9); "Tin tin de la Aguada/ Tin tin del Cerrito" (estr. 3); "Tin tin del Cerrito/ Tin tin del Cordon" (estr. 5) y, por último, "Tin tin del Cerrito/ Tin tin de la Aguada” (estr. 6).

Podría pensarse que las anteriores composiciones son de Ascasubi, incluyendo -como se adelantó- la que se dice que se había entonado a la hora del degüello. Estas piezas podrían verse como actos preparatorios de un artificio que el autor quiso imponer por su capacidad sonora y su fuerza expresiva, con la pretensión agregada de dotar al género de un alcance musical y hasta coreográfico (el rigodón, la media caña) a fin de volcarlo en la oralidad popular. En lo sucesivo, el inquieto poeta abandona la onomatopeya asociada a cualquier localización, quizá porque juzgó agotado el procedimiento. Más aun, porque su creador no logró que se continuara en la práctica de otros -o que sólo logró que por una vez Fernando Quijano la hiciera propia-, con lo cual perdió capacidad de diálogo. El estribillo infantil interrumpió su curso, no pudo desplazar al "Cielito, cielo que sî" y sus permutaciones (“Allá va cielo y más cielo”, etcétera), que todavía se mantuvieron algunos años más y rebrotaron en los años sesenta del siglo $\mathrm{XX}$ en los poemas políticos de Benedetti, entre otros, por ejemplo en "Cielo del 69”, que se hizo célebre en la interpretación de "Los Olimareños”. El "Tin, tin" ni siquiera se sumó al ramillete léxico arquetípico que atraviesa, intacto, varias décadas, como el uso de matungo o maturrango o las imágenes que se alinean en acusada frecuencia intertextual como la del tabaco de mala calidad asociado a la derrota del enemigo ("han pitar del más flojo"). De hecho, la reinvención sonora de Ascasubi sólo gozó de buena fortuna durante menos de un trimestre de 1843.

En suma, un autor concreto procesó cierto motivo oral para conseguir determinado efecto creativo novedoso y a la vez circunstancial, 
como siempre en este nivel de escritura. Tradición y transmisión orales se licuan en este caso fascinante, tanto que los dos primeros versos llegan hasta el presente. Un internauta, en 2006, recordó entre las canciones de su infancia una que decía: "Tin tin de la Aguada/ Tin tin del Cordón/ La negra ladrona/ y el negro ladrón”. Otros la evocan sustituyendo los dos últimos versos por "La negra Simona/ y el negro Simón”, líneas que comparten la estructura rítmica. Otros, menos, sustituyen la primera línea por "Tin tin de la galerita". ${ }^{1}$ En la versión que fuere, la copla ya estaba instalada en Montevideo hacia 1843, como lo anuncia el pasaje que se antepone a la trascripción que despliega el proceso. Con su fino oído y su olfato para dotar de beligerancia al verso gauchesco, Ascasubi vio el filón. Entonces, adaptó la letra fingiendo que los verdugos se apropiaban de tan inocente canción, preservando en ella imágenes pueriles ("gallina guisada/ Pato con arroz"), agigantando por contraste la ferocidad del acto en que incurrían, lindantes con el canibalismo. Como si los degollados fueran un apetitoso menú. ${ }^{2}$

La oralidad tuvo la fuerza suficiente para hacernos llegar esta letra de canción infantil, en la mayor parte de los ejemplos conservando intactas las dos primeras líneas. Pero no sería descaminado argumentar que el empeño de Ascasubi en escribir un poema tras otro en menos de noventa días de 1843, ayudó a que ese texto se consolidara en la memoria colectiva. Quizá el estribillo tan virtuosamente dispuesto en la "Media caña salvaje del Rio Negro", que hoy puede leerse íntegra en más de un sitio de Internet, fue retenido por algunos sujetos y luego se generalizó. La escritura podría haberlo fijado en la memoria de adultos que fueron niños y que, cuando entonces, la recibieron de otros adultos. Si así fuera, Ascasubi habría alcanzado un raro objetivo del género, ya que por vía indirecta refolklorizó un motivo folklórico. Ascasubi apuntó a la "gris tonalidad" del "hombre de todos los días [...] donde vive normalmente la verdad folklórica", para decirlo con las palabras de Ayestarán (1949: 202). Ese objetivo muestra, una vez más, la distancia entre el verso que se instala en la memoria de una colectividad, indiferente a la noción de autoría, y la condición letrada del verso gauchesco, que es escritura que persigue (y sólo a veces alcanza) la memoria del colectivo.

Quizá por esta diferencia, en la época inicial la anonimia fortalece el simulacro de lo folklórico. Poco después, sobre todo luego del Martín Fierro, se harán raros los textos sin firma. A lo sumo, se emplearán seudónimos, muchas veces como una manera de desdoblamiento, que se asume públicamente (Calisto el Ñato, por ejemplo, que a veces se duplica en la identidad real de Alcides de María), ya lejos de aquellos años primeros cuando los que borronean unos versos por belicosidad, afán pedagógico o divertimento, ocultaban su buen nombre.

Nunca tan radical la experiencia comunicativa obsesionada por la captura de un escucha popular como el ámbito de la inmensa constelación textual llamada literatura gauchesca, a la que Josefina Ludmer caracterizó

\author{
${ }^{1}$ La búsqueda de los \\ versos formularios \\ en Internet fue \\ realizada, por última \\ vez, el 4 de agosto \\ de 2010.
}

\footnotetext{
${ }^{2}$ Esto aunque la carga racista de las versiones evocadas contemporáneamente contengan, como muchas canciones infantiles, su particular carga de violencia $y$, para el caso, de discriminación.
} 
con la exacta fórmula de “uso letrado de la cultura popular" (Ludmer, 1988: 12). Esta idea de la investigadora argentina nos remite a otra, más reciente y global de Roger Chartier y que resulta aprovechable para la gauchesca. Para Chartier la cultura popular es "una categoría erudita", porque los debates sobre la misma sólo se generan entre los que así califican a estas manifestaciones (Chartier, 2003: 161). Dicho de otro modo, los creadores de cultura popular no se piensan a sí mismos como tales, en cuanto no analizan el proceso que los hizo posibles y no cuestionan la mecánica que pueda desactivar los engranajes de su producción.

Sabemos de sobra que los gauchescos participan de la historia del género, es decir que tienen una autoconciencia creativa que los sumerge en un conjunto de técnicas y códigos. Pero hay algo más que esa cadena que engarza códigos comunes y públicos preparados para recibirlos, porque sólo algunos pocos son capaces de introducir variantes propias, desviar la norma, que es lo que, al fin y al cabo, distingue el hacer colectivo de las muestras singulares. Muchos de los gauchescos -en rigor, la mayoríasiguen con docilidad las rutinas del régimen de escritura en el que se inscriben. Se podría postular que la prosecución de la práctica entre ellos se asemeja a la usanza del poeta popular: repetición de fórmulas y tópicos, mínimo distanciamiento crítico sobre el quehacer estético, afirmación de un lenguaje al que se atiende con respeto, es decir, se lo convierte en tradición. Hay, en ese orden, una convicción largamente compartida sobre la existencia de un circuito de comunicación con ese pueblo que debe ser controlado, ya sea en el sentido más duro (civilizarlo) como en el más discursivo (interpretarlo), operación que infiltra tanto las formas de contacto como las del contrato de representación que, al cabo, afecta el mismo debate entre los letrados que eligen este camino.

En 1850, cuando la guerra se apagaba, mientras maduraban los intelectuales argentinos exiliados y los montevideanos, salieron varios libros relevantes. Entre otros, las dos ediciones de Montevideo ou une nouvelle Troie, de Alejandro Dumas (una en francés, otra en español); la Colección de memorias y documentos para la historia y jeografía de los pueblos del Río de la Plata, de Andrés Lamas y Los mellizos o rasgos dramáticos de la vida del gaucho en las campañas y praderas de la República argentina, de Hilario Ascasubi. Hecho en la Imprenta de la Caridad, lanzado en dos entregas de poco más de cuarenta páginas cada una, con sus respectivos vocabularios, esta reunión de versos gauchescos es la primera que, juntos los dos folletos, se encuadernó en un libro de noventa páginas. El acontecimiento -así se lo consideró-, fue adelantado pocos días antes en El Comercio del Plata, el 21 de junio de 1850, en una carta autoexegética, casi una poética, que Ascasubi cerró con este mensaje: "Se admiten suscriptores en la librería de la calle 25 de Mayo $N^{\circ} 230$; en la botica del Sr. Las Cazes, calle de Sarandí No 164; y en el escritorio del Sr. Mainez, calle de Misiones $N^{\circ} 71$ ”. Esta y otras informaciones prueban que 
en Montevideo había cambiado el circuito de producción de una literatura -gauchesca o no- de la amalgamada pléyade argentina.

Pero, de todos modos, tan estrecho era el círculo de los interesados por las "bellas letras" en aquella ciudad sitiada y pequeña, que el retorno de capital era muy difícil para quien, como Ascasubi, necesitaba del aporte económico del público para editar su obra: "Mañana a las 10 del día avisa el poeta en El Correo de la Tarde de Montevideo, el 31 de agostose repartirá á los señores suscriptores la segunda entrega de esta obra, suplicándoles se dignen no demorar el pago de ella por los perjuicios que de esa demora le resultan al autor para verificar la recaudación” (En Weinberg, 1974: 16).

Esos "señores suscriptores" eran hombres y letrados, no las mujeres de la clase social hegemónica, ajenas a la lengua "bárbara". Ni el costo del impreso estaba al alcance de un público popular ni el periódico de la burguesía urbana por el que se divulgaba podía incorporarlo ni la práctica de la suscripción llegaba ni llegó nunca a este vasto círculo. Aun más, el analfabetismo obstaculizó la pretendida difusión masiva de las hojas poéticas o doctrinarias entre los paisanos que "servían" en cualquiera de los bandos en pugna. De ahí que las dirigencias ensayaran otra táctica propagandística: distribuir entre sus tropas y las del enemigo algunas caricaturas de los más altos dirigentes acompañadas por breves textos. Algunas de estas piezas fueron descubiertas en el archivo de un diplomático brasileño en Montevideo durante la Guerra Grande. Estamos ante otro capítulo en la guerra de los signos, solidaria con la anterior, para retener los favores de la irreductible masa popular, cuyos componentes de base podían alistarse en las fuerzas de un jefe hoy y mañana en las de su antagonista.

La defección del rosismo del General Urquiza y el apasionante ejemplo de la lucha de las imágenes litografiadas pone en evidencia estos temores. En 1851 Juan Manuel de Rosas se quedó sin el apoyo de Urquiza. Cercado y solo, mandó que se difundiera entre sus hombres y también entre los que se alistaban entre los de excompadre, un dibujo alegórico que presenta a una encorvada figura humana, el emperador de Brasil Don Pedro II, quien carga un pesado cajón con un cartel en portugués: "Vende-se". Lo martirizan dos figuras repelentes: el mismo diablo junto a un flaco y alucinado guerrero vestido con armadura y con una espada en su siniestra. A cierta distancia, en una suerte de altar custodiado por dos leones, se encuentra el escudo de la Confederación. Debajo, un largo texto explica el significado de cada imagen e increpa, en cada punto, al que invariablemente llama "Loco, Traidor, Salvaje Unitario Urquiza", "que después de vender su Patria al oro Brasilero [...] tiembla y quiere huir -por más que sus Amos Compradores lo empujan” (Soares de Souza, 1955: figs. 3-4). Esta afrenta al "pérfido, desleal, iniquo emperador del 
Brasil" hace reaccionar al Consejero Honório Hermeto, representante del Imperio en Montevideo. El 30 de diciembre de 1851, sabiendo que el gobierno de la Confederación había desparramado la antedicha ilustración entre filas urquicistas, escribió desde Montevideo al Ministro de Negocios Extranjeros solicitando que se lo autorizara para imitar el procedimiento. Una vez que tuviera caricaturas antirrosistas, "eu as mandaria espalhar em Buenos Aires e por entre o exército invasor com ventagem”. Gracias a un inesperado giro, el plan de infiltración y contrainteligencia se cumplió de inmediato. Por esos días el dibujante Rafael Mendes de Carvalho había llegado a Montevideo procedente de Entre Ríos, y el Consejero Hermeto lo contrató para que hiciera cuatro dibujos que degradaran a Rosas, las que prestamente se imprimieron en litografía. Satisfecho con el trabajo de su compatriota, el 22 de enero siguiente informaba a su superior que "uma porção de caricaturas que tinha encomendado ao nosso patrício Rafael", las "mandei espalhar grande número delas pelo Exército em operações, $e$ em Buenos Aires. Tiraram-se novecentos e tantos exemplares, cujo custo ainda ignoro, porque Rafael até este momento não remeteu-me a conta que exigi" (Soares de Souza, 1955: 10-11). Los números hablan claro del exacto consumo popular de estas formas de representación.

En un mundo desprovisto de imágenes, por su veloz eficacia comunicativa entre los iletrados, lo icónico era más peligroso que la escritura. Al primer contacto visual la estampa inclemente trasmite ideología y facilita el rechazo visceral de los endemoniados y locos. Con estos dos recursos se trata de crear afinidades a flor de piel entre quienes se supone incompetentes para descodificar mensajes complejos y sospechosos de una dudosa lealtad a convicciones y jefes. Esta y otras imágenes caricaturales siempre están acompañadas por palabras injuriosas, las que si bien tienen una función explicativa sirven más como significantes de la imagen escarnecedora. Roland Barthes dice que la fotografía punza (Barthes, 1999: 65). La caricatura grotesca ofende el ojo del contemplador que, instantáneamente, se sobresalta y descodifica el mensaje destructor que por su fácil inteligibilidad promueve la adhesión o la repulsa.

Hay otro dibujo-volante de propaganda rosista, también torpemente alegórico, que exhibe a un monstruo de dos caras como "Retrato del Loco, Traidor, Salvaje Unitario Urquiza descargando su pesada Carga... de Crímenes sobre el derecho de Gentes". El cargamento consiste en palabras: "Viva la anarquía", "villanía”, "noticias falsas”, "máscaras", “calumnias”, “traición”, “puñales”, “despotismo”, “ingratitud” (Soares de Souza, 1950: fig. 2). Imagen y palabras se complementan para subrayar la retórica del clisé y la diatriba, que en rigor se traslada del lenguaje oficial de decretos y proclamas. De hecho, estas palabras atraviesan varios registros: del discurso oficial a la propaganda que combina imagen y texto y también a muchos versos contemporáneos. Una proclama firmada por el Presidente Oribe, que salió de la Imprenta del Ejército el 30 de 
julio de 1851, compendia casi el mismo repertorio léxico que el dibujo antiurquicista. Empieza con la consigna oficial (" $i$ Vivan los Defensores de las Leyes! ¡Mueran los salvajes unitarios!”) y da aviso a los “orientales” sobre el "desertor de la sagrada causa que defienden las Repúblicas del Plata”, el "traidor Urquiza”, burlador de la "confianza del Gefe ilustre que preside los destinos de la Confederación” (es decir, Rosas), con el cometido de "trastornar el orden" (esto es, sembrar la "anarquía"), y reproducir "el luto, la devastación y todos los horrores de la guerra". Urquiza es calificado en el resto del documento como "pérfido", "vil juguete de los que antes trató como á mortales enemigos", "degenerado", "vil salvage unitario", "ingrato", "asociado con el bando de feroces salvages unitarios" y "tránsfuga infame” (Oribe, 30/VII/1851).

Esta serie de agravios que roza lo escatológico, procedimiento central y redundante en los despachos oficiales y los dibujos, urde el núcleo semántico elemental de los poemas más airados. Si los poemas luego pueden desplegarse con un lenguaje inventivo, al que contribuye la masa sonora, nunca dejan de formar parte de una semiótica orgánica que predica lo inconciliable, la muerte del enemigo. En suma, un discurso monológico. Aunque previo a la defección de Urquiza, un buen ejemplo de la estabilidad de este vocabulario, que no se arredra ante la náusea y, aun más, la propone, es el "Tónico para los salvages unitarios, tan hambrientos como rotosos que se hallan encerrados en la infeliz plaza de Montevideo”, firmado por el Licenciado vesugero Vasco-agarras Maniqui. El hablante poético disfraza su identidad en la voz que exhorta en futuro imperfecto a una segunda persona, que surge por la desinencia verbal y unas pocas marcas pronominales (“A esto vos le aumentarás", décima 1). Como en los mandamientos bíblicos, el futuro es una forma de imposición que subordina al otro. Ese, el que está en Montevideo, el agente de la acción (el que preparará el tónico), de acuerdo con el largo paratexto titular se multiplica por sinécdoque en toda la dirigencia refugiada tras las murallas: el Pardejón Rivera, el coronel Luna, Vázquez el Peluquín, Joaquín Suárez y Florencio Varela. Antecedido por la consigna del Cerrito, lo cual le asigna al poema un inequívoco carácter oficial, el relato versificado vuelve grotesca a esa galería de personajes con el registro reconocible: "osamentas salvajunas", "imbecil", "diablo entisicado", "vil ladron", "rudo vegete”, "salvage, inmundo". Sólo en una ocasión, en la última de las siete décimas, queda lugar para que los epítetos se expresen con ironía. Pero ese movimiento apenas es un amague de renuncia a la denotación más cruda, porque la dirección injuriosa se descodifica fácilmente en el título y las primeras estrofas, y porque el destacado en el original establece la distancia entre el primer nivel de sentido y el buscado aserto que descalifica:

Después de haberte aplicado

Esta Receta admirable 
De renuncia irrevocable

Harás un condimentado:

Luego con un plan chingado

Del sabio y sagaz Rivera

Te emplastarás la mollera

Para aliviar el dolor

Y no sentir el calor

de la furiosa carrera.

Veinte años después de la publicación de "Los mellizos...", umbral de la tarea gauchipoética de Ascasubi, las cosas cambian para el género con la gran difusión del Martín Fierro entre públicos rurales de Argentina y Uruguay, que agotaron miles de ejemplares de la obra a un ritmo desconocido hasta entonces en América Latina (Prieto, 1989; Rivera, 2001). Cierto que esto sucede cuando en la margen occidental del Plata la guerra civil ha dejado paso al orden, cuando ya la demografía y la alfabetización ha hecho enormes avances y la gauchesca ha encontrado ese texto clave, editado en precarios folletos. Por eso mismo, Hernández llegó antes que su antecesor a públicos vastos, que para su beneplácito pertenecen más a las áreas rurales que a los centros urbanos. Ascasubi cumplió su papel de difusor de su ideología estética y política en tiempos de la guerra contra Rosas. En su vejez rescató esos versos de gacetas y hojas que el tiempo se había llevado para que, juntos, se transformaran en obra. Al tiempo que Ascasubi monumentaliza su labor poética, Hernández iniciaba aquella intervención de su antecesor en otro escenario y con otras posibilidades materiales: más lectores-auditores, mejor tecnología, una tradición poética que lo respaldaba. Pero no olvidó que la imagen era un soporte necesario para un lector mal entrenado, y en los folletos de la Ida y de la Vuelta incluyó estampas, entre realistas e idílicas, que se reprodujeron en xilografías, que al cabo se borronearon por su empleo en las continuas reediciones. ${ }^{3}$ Las alegorías atroces o las ilustraciones hirientes impresas en 1851-52 cedieron espacio a la pastoral, que homologaba lo campesino con lo nacional auténtico. Actuar sobre el presente era el destino que Hernández le reservó al Martín Fierro. La canonización, se sabe, vendrá mucho después. Sin éxito, Sarmiento haría lo posible para frenarla.

\section{Bibliografía}

\section{Corpus}

AYESTARÁN, Lauro (compilador) La primitiva poesía gauchesca (18121838). Revista del Instituto Nacional de Investigaciones y Archivos Literarios, Montevideo, Año 1, n.1, p.261-491, 1949. [Recopilación de poemas gauchescos tomados de prensa periódica de la época en

\author{
${ }^{3}$ En un ejemplar de \\ 1897 de la Vuelta, \\ que perteneció a \\ Juan José Morosoli, \\ anunciado como \\ décima edición \\ por la "Librería \\ Martín Fierro”, las \\ imágenes están tan \\ borrosas que apenas \\ se las percibe, un \\ poco por el deterioro \\ del papel de baja \\ calidad y otro tanto \\ por el desgaste \\ que sufrieron las \\ maderas en su muy \\ frecuente impresión. \\ (El ejemplar \\ mencionado en \\ Colección Juan José \\ Morosoli, Caja 12 B, \\ Sección de Archivo \\ y Documentación \\ del Instituto de \\ Letras, FHCE, \\ UdelaR, www.sadil. \\ fhuce.edu.uy).
}


Montevideo, hojas volantes, recopilaciones y libros. Original en el Archivo Lauro Ayestarán, donado en octubre de 2010 por el autor de este artículo, quien lo adquirió en junio de ese año].

HIDALGO, Bartolomé Obra completa. Montevideo, Colección de Clásicos Uruguayos, Biblioteca Artigas, 1986. (Prólogo de Antonio Praderio).

ORIBE, Manuel (30/ 07/1851). Proclama [contra el General Urquiza]. Reproducción facsimilar en "Manuel Oribe. Contribución al estudio de su vida, 1851-1857”, Elisa Silva Cazet. Revista Histórica, Montevideo, t. 41, p.121-123, diciembre de 1970. Lámina 10.

ORIBE, Aquiles B. La literatura de combate y las muchedumbres durante la Guerra Grande. In: CONFERENCIAS DEL CURSO DE 1937. Montevideo, Instituto Histórico y Geográfico del Uruguay: 257-282, 1937. Anais... [Incluye selección de piezas gauchescas editadas en el Cerrito].

RODRÍGUEZ MOLAS, Ricardo. Luis Pérez y la biografía de Rosas escrita en verso en 1830. Buenos Aires: Clío, 1957. [Incluye el poema "El gaucho", de Luis Pérez, publicado en 1830. La edición adolece de numerosas erratas].

Contribución a la bibliografía de Hilario Ascasubi (18071875). Buenos Aires, Fondo Nacional de las Artes, 1961. [Reproduce en forma facsimilar el $\mathrm{N}^{\circ} 1$ de El Arriero Argentino, Montevideo, 2 de setiembre de 1830, p.77-80].

SARMIENTO, Domingo F. Facundo o civilización y barbarie. Caracas, Biblioteca Ayacucho, 1977. (Prólogo de Noé Jitrik. Cronología de N. Dottori y S. Zanetti) [1845].

. Viajes por Europa, África y América 1845-1847 y Diario de gastos. Buenos Aires, Colección Archivos/Fondo de Cultura Económica de Argentina, 1993. (Edición crítica: Javier Fernández, (Coord.).

SOLANO ANTUÑA, Francisco. Contribuciones documentales: escritos históricos, políticos y jurídicos del Dr. Francisco Solano Antuña. Revista Historica, t. 65. Historia de América. Montevideo, 2a época, n.133-135, julio: p.380-527, 1974. (Presentación de Elisa Silva Cazet [1843]).

\section{Teoría, historia y crítica}

ANGENOT, Marc. La parole pamphlétaire: typologie des discours modernes. Paris : Payot, 1982. 
AYESTARÁN, Lauro. La primitiva poesía gauchesca (1812-1851). Revista del Instituto Nacional de Investigaciones y Archivos Literarios, Montevideo, año I, n.1, p.201-260, (1949). [Y en separata con numeración correlativa. Constituye el prólogo de esta recopilación].

. El folklore musical en la obra de Figari. En:

práctica del folklore. Montevideo: Arca, 1968. p.75-79. Teoría y

BARTHES, Roland. La cámara lúcida. Nota sobre fotografía. Barcelona: Paidós, 1999. [1980]. (Traducción de Joaquín Sala-Sahanuja).

CHARTIER, Roger. Leituras populares. In: Formas e sentido: cultura escritura: entre distinção e apropriação. São Paulo, Mercado das Letras, 2003. p. 141-167. (Tradução de Maria de Lourdes Meirelles Matencio). [1995].

FONTANELLA DE WEINBERG, María Beatriz. La «lengua gauchesca» a la luz de recientes estudios de lingüística histórica. Filología: Buenos Aires, t.21, n.1, p.7-23, 1986.

GRAMSCI, Antonio. Letteratura e vita nazionale, Antonio Gramsci. 3.ed. Torino: Einaudi, 1953.

HUTCHEON, Linda. A theory of parody: the teachings of twentiethcentury art forms. New York: Routledge, 1991.

JITRIK, Noé. El tema del canto en el Martín Fierro de José Hernández. En: Suspender toda certeza (Antología crítica, 1959-1976). Buenos Aires: Biblos, 1997. p.33-63. (Selección y prólogo: Gonzalo Aguilar y Gustavo Lespada). [1970].

LUDMER, Josefina. El género gauchesco: un tratado sobre la patria. Buenos Aires: Sudamericana, 1988.

PRIETO, Adolfo. El discurso criollista en la formación de la literatura argentina. Buenos Aires: Sudamericana, 1989.

RAMA, Ángel. Los gauchipolíticos rioplatenses. Buenos Aires: Centro Editor de América Latina (2.ed.ampl.), 1982.

RIVERA, Jorge B. La paga del gauchesco. Clarín: cultura y nación. Buenos Aires: 18 de mayo, 1989. p.2-3.

. Ingreso, difusión e instalación modelar del Martín Fierro en el contexto de la cultura argentina. En MARTÍN FIERRO, José Hernández. (Edición crítica: Élida Lois y Ángel Núñez, Coords.). Madrid: Colección Archivos, 51. UNESCO, 2001. p.545-575.

ROCCA, Pablo. Poesía y política en el siglo XIX (una cuestión de fronteras). Montevideo: Banda Oriental, 2003. 
RODRÍGUEZ MOLAS, Ricardo. Historia social del gaucho. 2.ed. amp. y correg. Buenos Aires: CEDAL, 1982.

SCHVARTZMAN, Julio. El gaucho letrado. En: Microcrítica: lecturas argentinas (Cuestiones de detalle). Buenos Aires: Biblos, 1996. p.157-175.

. A quién cornea El Torito: notas sobre el gauchipolítico Luis Pérez. En: Letras y divisa: ensayos sobre literatura y rosismo. Cristina Iglesia (comp. y prólogo). Buenos Aires: Eudeba, 1998. p.13-23.

SOARES DE SOUZA, José Antonio. Um caricaturista brasileiro no Rio da Prata. Rio de Janeiro, em Revista do Instituto Histórico e Geografico Brasileiro, v. 227, abril-junho: 3-84 + 60 láminas, 1955. [Separata].

ZUMTHOR, Paul. La letra y la voz de la "literatura” medieval. Madrid: Cátedra, 1989.

WEINBERG, Félix. La primera versión del "Santos Vega” de Ascasubi: un texto gauchesco desconocido. Buenos Aires, Fabril, 1974. [Reproduce Los mellizos o rasgos dramáticos de la vida del gaucho en las campañas y praderas de la República argentina por H.A., Montevideo, Imprenta de la Caridad, 1850]. 